\author{
Achmad Ismail* \\ Universitas Jakarta, Indonesia
}

\title{
Makmur Keliat
}

Universitas Indonesia, Indonesia

\begin{abstract}
Abstrak
Family Smoking Prevention and Tobacco Control Act (FSPTCA) merupakan tindakan diskriminasi yang dilakukan oleh Amerika Serikat terhadap rokok kretek Indonesia. Karena itu, Indonesia meresponnya dengan menyengketakannnya ke Dispute Settlement Body World Trade Organization (DSB WTO). Amerika Serikat diputus bersalah dan diperintahkan untuk mematuhi rekomendasi panel dan Badan Banding karena melanggar prinsip non-diskriminasi WTO. Indonesia pun meminta otorisasi DSB WTO untuk retaliasi. Namun, yang terjadi adalah retaliasi dengan menandatangani Mutually Agreed Solution/Moratorium of Understanding untuk mengakhiri sengketa perdagangan FSPTCA. Artikel ini menjelaskan mengapa pemerintah Indonesia tidak melakukan retaliasi sesuai otorisasi DSB WTO, tetapi memilih retaliasi dengan menandatangani Mutually Agreed Solution/ Moratorium of Understanding dengan menggunakan two-level game theory sebagai model analsisinya. Data yang diperlukan dikumpulkan melalui wawancara dan studi pustaka. Artikel ini berargumen bahwa Indonesia tidak melakukan retaliasi sesuai otorisasi DSB WTO terhadap Amerika Serikat, melainkan melakukan retaliasi dengan menandatangani Mutually Agreed Solution/MoU, dikarenakan Amerika Serikat menawarkan poin-poin yang dianggap lebih signifikan dan sesuai dengan kebutuhan Indonesia.
\end{abstract}

\section{Kata-kata Kunci}

Kebijakan luar negeri, FSPTCA, retaliasi, two-level game theory 


\section{Abstract}

This article explains why the Indonesian government did not retaliate the USA according to the DSB WTO authorization, but rather opted to retaliate in the form of signing a mutually agreed solution/MoU in the case of the Family Smoking Prevention and Tobacco Control Act (FSPTCA). FSPTCA was regarded as a discriminatory act issued by the USA against Indonesia's clove cigarettes. Indonesia responded by disputing it into the Dispute Settlement Body World Trade Organization (DSB WTO). The USA was found guilty because it violated the WTO principle of non-discrimination and so that it was ordered to comply with the Panel and Appellate Body's recommendation. Indonesia then requested DSB WTO authorization to carry out retaliation. However, Indonesia did not retaliate according to DSB WTO authorization, but rather opted to sign a mutually agreed solution/MoU (Moratorium of Understanding) to end the FSPTCA trade dispute. Using two-level game theory as its analytical framework, this article argued that Indonesia decision to sign a mutually agreed solution instead of retaliation against the USA was driven by the fact that agreement was considered much more significant and suitable to Indonesia interests.

\section{Key Words}

Foreign policy, FSPTCA, retaliation, two-level game theory

\section{Pendahuluan}

Peningkatan aktivitas sengketa perdagangan sejalan dengan peningkatan aktivitas perdagangan. Hal ini menandakan bahwa dalam melakukan aktivitas perdagangan, negara kerap kali membawa kepentingannya masing-masing. Benturan kepentingan nasional antar negara menjadi salah satu penyebab sengketa perdagangan yang terefleksi dalam World Trade Organization (WTO) (Winarno 2014).

WTO ini tidak hanya memfasilitasi perdagangan, tetapi juga memfasilitasi beberapa sengketa perdagangan antar negara anggota WTO. Sejak 1995 hingga September 2019, setidaknya ada 590 perselisihan telah dibawa ke WTO ("Current Status of Disputes"). WTO pun sudah mempunyai mekanisme penyelesaian sengketa perdagangan. Mekanisme ini menjadi salah satu kabar baik bagi anggota WTO, terutama bagi negara berkembang saat ini demi menciptakan suatu sistem persengkataan dagang yang berkeadilan. 
Berdasarkan GATT Annex 2 tentang "Understanding on Rules and Procedures Governing the Settlement of Disputes Agreement WTO", penyelesaian sengketa dagang dalam institusi WTO harus melalui empat tahap aturan mekanisme penyelesaian, yaitu konsultasi, pembentukan panel (appellate), banding dan implementasi. Rangkaian mekanisme penyelesaian sengketa ini menjadi penting bagi negara yang bersengketa karena melalui mekanisme inilah mereka benar-benar menemui titik penyelesaian sengketa perdagangan secara adil.

Dari empat tahapan di atas, khususnya pada tahapan implementasi, ada suatu konsep yang dinamakan retaliasi (pembalasan). Secara singkat, retaliasi merupakan tindakan pembalasan suatu negara dalam perdagangan terhadap negara lain sebagai akibat dari tidak dipenuhinya rekomendasi panel dari sengketa perdagangan yang diputuskan oleh DSB WTO. Dalam aturannya, DSB WTO memberikan otoritas negara yang merasa dirugikan untuk melakukan retaliasi akibat melanggar komitmen atau perjanjian dari aktivitas perdagangan dengan negara lain dengan besaran nilai retaliasi yang dikenakan harus seimbang dengan nilai kerugian yang diterima akibat proteksi atau diskriminasi terhadap barang impor suatu negara.

Secara formal, retaliasi ini menjadi instrumen yang bertujuan menegakkan peraturan negara anggota WTO, khususnya negara berkembang untuk memberikan rasa adil dalam perdagangan. Namun, secara realitas negara yang memenangkan sengketa, khususnya negara berkembang, belum tentu memiliki keberanian untuk mengajukan tindakan retaliasi meskipun negara yang kalah tidak mau melaksanakan keputusan DSB WTO hingga batas waktu yang telah ditentukan (Davey 2005). Tidak dipungkiri banyak negara berkembang yang mengajukan penyelesaian sengketa perdagangan kepada DSB WTO. Namun, apabila hasil rekomendasi sengketa tersebut memenangkan negara berkembang dan negara lawan dari negara maju tidak melaksanakan hasil rekomendasinya, kerap kali negara berkembang kehilangan keberanian untuk melakukan tindakan retaliasi.

Hali ini terjadi pada Indonesia. Indonesia melakukan tindakan retaliasi dengan cara menandatangani mutually agreed solution sebagai akhir dari sengketa perdagangan dengan Amerika Serikat. Food and Drug Administration (FDA) menjelaskan bahwa bermula pada tanggal 22 Juni 2009 ketika National Institutes of Health (NIH) dan Food and Drug Administration (FDA) memberikan kajian kesehatan kepada kongres Amerika Serikat terkait aturan tembakau dengan mengeluarkan produk hukum tentang Family Smoking Prevention and Tobacco Control Act (FSPTCA) ("Family Smoking Prevention and Tobacco Control Act - 
An Overview"). Untuk melindungi kesehatan masyarakat, mendorong industri tembakau untuk ramah lingkungan dan mengatur kemasan dan pemasarannya, regulasi ini melarang produksi dan penjualan rokok beraroma dan rasa (flavoured cigarettes), termasuk di dalamnya rokok kretek, dengan pengecualian rokok menthol.

Merespon regulasi ini, pada 7 April 2010 Indonesia resmi melaporkan dan meminta konsultasi kepada WTO terkait sengketa perdagangan rokok kretek Amerika Serikat dengan Indonesia ("United States-Measures Affecting the Production and Sale of Clove Cigarettes (Request for Consultations by Indonesia)"). Namun, kedua belah pihak tidak menemukan kesepakatan hingga pertengahan Me 2010. Karena itu, pada 22 Juni 2010, secara resmi melalui Kementrian Perdagangan, Indonesia meminta pembentukan panel dalam sidang DSB WTO untuk menyelesaikan sengketa perdagangan ini ("RI Sengketakan Larangan Perdagangan Rokok Kretek di Amerika Serikat ke DSB-WTO").

Selama satu tahun lebih panel tersebut bekerja untuk menyelesaikan sengketa perdagangan ini hingga pada 2 September 2011 keluar rekomendasi panel yang bernama "United States - Measures Affecting the Production and Sale of Clove Cigarettes". Rekomendasi panel tersebut menerangkan bahwa Amerika Serikat terbukti melanggar pasal dalam perjanjian technical barriers to trade (TBT) karena memiliki dampak terhadap pelarangan impor rokok kretek Indonesia, tapi tidak melarang produksi dan penjualan rokok menthol sebagai produk serupa ("WTO Perkuat Putusan Kemenangan RI Soal Kretek").

Namun, Amerika Serikat mengklaim bahwa panel salah paham dalam menilai rokok kretek dan rokok menthol sebagai produk serupa dan panel juga keliru jika Amerika Serikat melanggar pasal dalam perjanjian TBT. Atas dasar inilah Amerika Serikat mengajukan banding ke Badan Banding WTO pada 5 Januari 2012, untuk meninjau kembali rekomendasi panel terkait kasus FSPTCA. Pada 4 April 2012, Badan Banding WTO mengkonfirmasi rekomendasi panel yang menerangkan bahwa Amerika Serikat melanggar ketentuan WTO sebagai bentuk diskriminasi dagang (Mulyadi 2012). Akibatnya, Amerika Serikat harus menyesuaikan rekomendasi dari panel dan Badan Banding untuk diadopsi ke dalam produk hukum FSPTCA selambat-lambatnya hingga 24 Juli 2013.

Respon negatif atau ketidakpatuhan Amerika Serikat terhadap hasil rekomendasi Badan Banding WTO ini membuat Indonesia menjadi geram. Tak lantas berdiam diri, Indonesia berupaya keras dengan berbagai macam cara, mulai dari mengingatkan Amerika Serikat agar segera mengadopsi rekomendasi panel dan Badan Banding hingga puncaknya pada tahun 
2013 Indonesia meminta otorisasi kepada DSB WTO untuk melakukan tindakan retaliasi terhadap Amerika Serikat. Tindak lanjutnya, DSB WTO memberikan otorisasi Indonesia untuk melakukan retalisasi dengan besaran nilai retaliasi yang diotorisasi mencapai angka US\$ 55 juta ("Indonesia dan AS Sepakat Akhiri Sengketa Rokok Kretek"). Sebenarnya, Indonesia tidak mempersoalkan besaran dari retaliasi, melainkan lebih menyayangkan tindakan diskriminasi yang dilakukan oleh Amerika Serikat dan melihanya sebagai tindakan melanggar hukum yang telah disepakati bersama dalam WTO.

Dalam perkembangan selanjutnya, meskipun telah diotorisasi oleh DSB WTO untuk melakukan retaliasi terhadap Amerika Serikat dengan nilai otorisasi US\$ 55 juta, Indonesia tidak melakukan retaliasi sesuai otorisasi DSB WTO. Indonesia melakukan retaliasi dengan menandatangani mutually agreed solution dengan Amerika Serikat untuk mengakhiri sengketa perdagangan FSPTCA. Di dalamnya, secara umum terdapat tiga poin yang dirasa signifikan bagi Indonesia, yaitu Generalized System of Preferences (GSP), Intelectual Property Rights (IPR) \& Cigarillos dan Mineral Ores Export Restraint. Hal ini tentu saja melahirkan banyak pertanyaan dan menarik untuk dikaji lebih dalam. Karena itu, artikel hendak menganalisis isu penting mengapa Indonesia tidak melakukan retaliasi sesuai dengan nilai otorisasi DSB WTO terhadap Amerika Serikat dalam kasus Family Smoking Prevention and Tobacco Control Act (FSPTCA).

Beberapa kajian terdahulu telah berupaya meneliti terkait kasus FSPTCA dari berbagai perspektif termasuk yuridis dan politis. Ballet (2011) memandang bahwa produk hukum terkait larangan AS terhadap rokok kretek tidak konsisten dengan kewajiban anggota WTO yang mematuhi prinsip Most Favoured Nation (MFN) dan National Treatment (NT). Hal ini dipandang sebagai tindakan diskriminasi di mana rokok kretek yang dilarang, tapi rokok menthol tidak dilarang. Lebih lanjut, produk hukum FSPTCA ini masuk ke dalam Technical Barriers to Trade (TBT), di mana tindakan tersebut melanggar pasal-pasal yang diatur oleh WTO dan dapat mengganggu aktivitas perdagangan internasional secara adil.

Dalam kajian lainnya, Voon (2012) setidaknya melihat dua masalah utama dalam kasus FSPTCA, yakni kebijakan ini tidak sejalan dengan perjanjian TBT pasal 2.1 dalam bentuk "like products" dan "treatment no less favourable". Kedua prinsip WTO inilah yang dilanggar atas keluarnya produk hukum FSPTCA. Pada hakikatnya, setiap negara dapat mengeluarkan produk hukum sebagai regulasi perdagangan nasional mereka. Namun, ada beberapa hal lainnya yang menjadi pertimbangan seperti ketentuan dari WTO. 
Penelitian oleh Fie, Devy dan Agustin (2015) berfokus pada analisis yuridis ditandatanganinya mutually agreed solution oleh Indonesia dan Amerika Serikat. Legalisasi sebagai akhir dari upaya penyelesaian sengketa dagang kasus FSPTCA diakui secara hukum nasional dan hukum internasional dan membawa keuntungan dan kerugian tersendiri bagi kedua pihak. Menurut mereka, legalitas mutually agreed solution sebagai akhir dari penyelesaian sengketa secara hukum nasional maupun internasional perlu diulas. Kekuatan hukum dari mutualli agreed solution ini tidak memiliki kekuatan tetap dan mengikat bagi kedua negara dan menyiratkan ketidakmampuan negara berkembang ketika berhadapan dengan negara maju.

Namun, kajian lain berpendapat bahwa keberhasilan Indonesia dalam sengketa perdagangan FSPTCA dengan Amerika Serikat merupakan suatu keberhasilan diplomasi Indonesia dalam mengedepankan kepentingannya di WTO (Oktavian 2012). Beberapa kasus sengketa perdagangan yang dihadapi oleh Indonesia dan berhasil dimenangkan menjadi pertanda bahwa proses diplomasi yang dilakukan oleh Indonesia berhasil sekaligus menandakan bahwa negara berkembang pun dapat menjadi pemain dengan power yang dimilikinya, mampu berhadapan dengan negara big power, dan memberikan pengaruh besar.

Penelitian lainnya berfokus pada dinamika internal Amerika Serikat di mana pemerintah berupaya mendapatkan pengaruh pada tataran domestik. Arisanto (2017) memaparkan bahwa pengaruh dinamika domestik yang saling bertentangan mempengaruhi pemerintah Amerika Serikat untuk mengeluarkan kebijakan FSPTCA yang diwarnai kontroversi akibat mengadopsi ketentuan Framework Convention on Tobacco Control (FCTC) dari WHO sebagai win-win solution. Adanya dinamika domestik Amerika Serikat yang bertentangan terkait upaya ratifikasi konvensi internasional FCTC oleh pemerintah Amerika Serikat sehingga dikeluarkannya produk hukum FSPTCA menjadi jalan tengah yang adil bagi pihak-pihak yang bermain.

Untuk memperkaya literatur yang dipaparkan di atas, artikel ini meneliti kasus FSPTCA dengan mengidentifikasi actor-aktor di lingkup Indonesia. Kajian ini merupakan deskriptif-analitis dengan pendekatan studi. Penelitian studi kasus secara intensif menyelidiki satu atau sekumpulan kecil kasus dan berfokus pada banyak detail dalam setiap kasus dan konteksnya (Neuman 2014). Data yang diperlukan dikumpulkan melalui kajian pustaka berupa buku, jurnal ilmiah, dokumen, media daring terkait, serta didkung oleh wawancara langsung dengan seorang analis kebijakan perdagangan dari Kementrian Perdagangan Indonesia 
Dengan menggunakan two-level game theory, artikel ini berargumen bahwa Indonesia tetap melakukan retaliasi terhadap Amerika Serikat, hanya saja retaliasi yang diterapkan tidak secara umum dalam sistem perdagangan WTO, yaitu salah satunya diterapkan dengan menaikkan tarif dari produk negara yang dikenakan retaliasi (Amerika Serikat) sesuai dengan nilai yang diotorisasi oleh WTO, melainkan dengan menandatangani mutually agreed solution.

\section{Two-Level Game Theory sebagai Kerangka Analisis}

Untuk menjawab masalah di atas, kami menggunakan two-level game theory. Secara sederhana, two-level game theory adalah suatu teori kebijakan luar negeri di mana para pengambil keputusan berupaya mendapatkan persetujuan dengan mitra asingnya dan di waktu yang bersamaan menemukan titik persetujuan dengan mitra domestiknya (Putnam 1988). Dari perspektif two-level games, para perwakilan pemerintah dipandang sebagai "chief negotiators" yang terlibat dalam beberapa bentuk negosiasi internasional yang pada akhirnya mereka perlu mendapatkan persetujuan domestik (ratifikasi) (da Conceição-Heldt and Mello 2017).

Memahami konsep kebijakan luar negeri menjadi salah satu perhatian penting Hubungan Internasional ketika ingin memahami bentuk tindakan suatu negara terhadap aktor lain di luar lingkungan teritorialnya (Purnama, Dermawan, and Mahyudin 2019). Belum lagi pembuat kebijakan akan merumuskan kebijakan luar negeri negara mereka sesuai dengan konsepsi peran yang ada, sehingga tidak hanya dapat merumuskan peran nasional dari dalam negaranya sendiri, melainkan juga dapat muncul dari lingkungan eksternal (Dermawan and Rohmaniah 2019).

Secara dinamika domestik, satu aktor domestik mendukung untuk merevisi kebijakan yang dituntut terhadap suatu negara secara internasional. Namun, tuntutan tersebut kerapkali bersinggungan dengan sesuatu yang terjadi pada level internasional sehingga ada tekanan dari mitra asingnya untuk menyetujui atau melakukan perubahan kebijakan lain.

Dalam two-level game theory, proses pengambilan keputusan dilakukan dalam dua level (Putnam 1988). Pertama, proses bargaining antara negosiator dengan mitra internasional, yang mengarah pada proses kesepakatan; ini Level I (level internasional). Kedua, diskusi terpisah antara negosiator (perwakilan negara) dengan kelompok konstituen (mitra domestik) terkait apakah akan meratifikasi perjanjian atau tidak; ini Level II (level domestik). 
Pada level I, para negosiator dari masing-masing negara tidak memiliki preferensi kebijakan independen melainkan membawa kepentingan dari konstituen (mitra domestik). Pada tingkat nasional/domestik, kelompok kepentingan dan konstituen (misalnya serikat pekerja, dan kelompok aktivis) bersikeras untuk mendapatkan kepentingan mereka dengan menekan pemerintah untuk mengambil kebijakan yang menguntungkan (Bjola and Manor 2018).

Sementara itu, pada Level II negosiator suatu negara dengan negosiator negara lain berdiskusi untuk menentukan kebijakan terbaik, merepresentasikan kepentingan seluruhnya kemudian dibawa ke Level I. Pada level ini atau tingkat internasional, pemerintah berupaya untuk memenuhi tekanan dan tuntutan konstituen domestik mereka, sementara pada saat yang sama meminimalkan kemungkinan dampak buruk dari pembangunan luar negeri (Bjola and Manor 2018).

Karena itu, akan selalu ada proses konsultasi atau tawar-menawar yang terjadi pada Level II untuk menentukan posisi awal dalam proses negosiasi pada Level I. Begitupun sebaliknya, kebutuhan untuk meratifikasi pada Level II pasti akan mempengaruhi pada proses negosiasi di Level I. Sehingga di banyak proses negosiasi, ratifikasi bersifat interaktif karena para perunding akan mencoba kemungkinan perjanjian lain dengan pertimbangan pandangan dari konstituen (mitra domestik) mereka masingmasing. Hal yang membuat kompleks, pandangan-pandangan ini akan terus berkembang selagi proses negosiasi berjalan. Meskipun demikian, ratifikasi pada Level II merupakan persyaratan mutlak pada setiap kesepakatan Level I. Sementara pada Level II, mitra domestik mengejar kepentingan mereka dengan memberikan pengaruh terhadap pemerintah untuk mengadopsi kebijakan yang memberikan benefit lebih sehingga mereka membangun koalisi sebagai akumulasi dari kepentingan mereka.

Dengan kata lain, interaksi antara kedua tingkat ini terwujud dalam kenyataan bahwa seorang pemimpin yang mengabaikan tekanan dalam negeri atau orang yang lebih menyukai politik dalam negeri di atas masalah internasional tidak akan berhasil meratifikasi atau menegosiasikan perjanjian (Bjola and Manor 2018). Oleh karena itu, Putnam menerangkan bahwa pada Level I, pemerintah nasional sebagai representatif atau negosiator berusaha keras untuk memaksimalkan kemampuan mereka untuk mengakomodasi tekanan domestik, sekaligus meminimalkan opsiopsi terburuk dari perkembangan mitra internasional mereka (Putnam 1988). 
Kompleksitas pada proses ratifikasi pengambilan keputusan Level I dan Level II dapat dijelaskan dengan konsep win-set (Putnam 1988). Secara sederhana, win-set ini merupakan sebuah kesepakatan dengan konstituen domestik (Level II) sebagai pedoman tetap terhadap proses ratifikasi pengambilan keputusan di internasional (Level I). Menurut Putnam (1988), terdapat dua poin dalam konsep win-set ini. Pertama, winset yang lebih besar diperoleh oleh kedua negara membuat kesepakatan akan lebih memungkinkan. Kesepakatan yang berhasil terjalin merupakan kemenangan dari aktor Level II dan masing-masing pihak pada perundingan. Kedua, ukuran relatif dari win-set pada Level II akan memberikan pengaruh distribusi keuntungan bersama dari proses negosiasi level internasional. Mo (1995) memberikan penjelasan bahwa kemampuan dari negosiator untuk mempersempit win-set nya dengan memberikan hak veto kepada aktor domestik atas sebuah perjanjian internasional mengakibatkan peningkatan posisi tawar pada Level I. Demikian pula, para negosiator menggunakan ketidakpastian pada proses ratifikasi Level II sebagai pengaruh pada negosiasi Level I (Keisuke 1993).

Lebih lanjut, Putnam (1988) menjelaskan tiga faktor determinan yang merumuskan ukuran win-set terbentuk. Pertama, preferensi dan koalisi pada level II. Putnam menjelaskan bahwa dalam distribusi preferensi dan koalisi ini, ada tiga poin penting yang menentukan sebuah ukuran winset, yaitu (1) adanya biaya dari no-agreement (menggambarkan status quo) yang semakin rendah bagi konstituen menyebabkan semakin kecil pula sebuah win-set, begitupula sebaliknya; (2) ukuran win-set yang diputuskan bersifat relatif berdasarkan kekuatan isolasionist (menentang kerjasama internasional) dan kekuatan internasionalist (mendukung kerjasama internasional); (3) preferensi konstituen (homogen atau heterogen) pula mempengaruhi besaran win-set yang ditentukan. Preferensi homogen dikatakan sebagai boundary conflict dan heterogen dikatakan sebagai factional conflict. Boundary conflict terjadi ketika negosiator mengalami dilemma kepentingan di antara konstituennya dan organisasi eksternal, sementara factional conflict terjadi ketika negosiator mengalami dilemma kepentingan di antara faksi-faksi yang bersaing di dalam organisasinya; dan (4) perbedaan tingkat partisipasi (preferensi) pada setiap aktor domestik mempengaruhi ukuran win-set.

Kedua, struktur lembaga politik atau institusi pada Level II memiliki pengaruh terhadap ukuran win-set dalam hal berikut: (1) prosedur pengambilan ratifikasi, di mana negosiator membutuhkan persetujuan dari dua pertiga legislatif untuk menentukan persetujuan tersebut untuk ratifikasi lanjutan; dan (2) besaran otonomi sebuah negara yang menentukan besaran 
sebuah win-set. Negara yang memberikan keluasan bagi mitra domestiknya sebagai preferensi (demokratis) semakin besar win-set mereka untuk mencapai kesepakatan internasional serta menaikkan posisi tawarnya dalam perundingan internasional (Level I). Sebaliknya, jika negara tidak mempertimbangan bagi mitra domestiknya sebagai preferensi (otoriter), maka win-set yang dihasilkan semakin kecil dan posisi tawarnya lemah dalam perundingan internasional (Level I).

Ketiga, strategi negosiator di Level I mempengaruhi besaran win-set. Negosiator melakukan berbagai upaya untuk memperbesar win-set guna mencapai kesepakatan. Untuk mencapainya, negosiator menggunakan instrumen side-payments dan generic good will. Side-payments digunakan untuk mencari pendukung marjinal dan besarannya dihitung sesuai kontribusi marjinal memungkinkan untuk ratifikasi. Generic good will adalah all-purpose glue untuk koalisinya untuk memperbesar win-set, walaupun tidak menjamin proses ratifikasi pada Level I.

\section{Tindakan Retaliasi Indonesia dengan Mutually Agreed Solution}

Bagian ini menjelaskan alasan-alasan yang membuat pemerintah Indonesia tidak melakukan retaliasi sesuai nilai otorisasi DSB WTO, melainkan melakukan retaliasi dengan mutually agreed solution. Untuk mendapatkan alasan-alasan tersebut di atas, harus dianalisis terlebih dahulu mengenai win-set pada Level II (domestik) dan Level I (internasional) sebagai pijakan dalam mengambil suatu kebijakan. Lebih lanjut, ada tiga faktor dominan pembentuk win-set dalam two-level game theory.

\section{Preferensi dan Koalisi pada Level II}

Preferensi dan koalisi pada Level II menjadi salah satu indikator penting untuk mengetahui proses pengambilan keputusan aktor-aktor domestik Indonesia terkait kasus FSPTCA. Selanjutnya, preferensi dan koalisi pada Level II (domestik) dianalisis lebih mendalam melalui aktor-aktor dominan yang menjadi penentu berakhirnya kasus FSPTCA tidak dengan retaliasi sesuai nilai yang diotorisasi oleh DSB WTO melainkandengan mutually agreed solution.

Kementerian Perdagangan (Kemendag)

Kemendag memiliki posisi yang sangat krusial di mana Kemendag menjadi focal point pada Level I dan menjadi pemrakarasa pada Level II. Hal ini dibuktikan dengan Kemendag melakukan diplomasi baik bilateral maupun multilateral, sekaligus menginisiasi para aktor domestik terkait untuk 
melakukan rapat koordinasi dalam kasus FSPTCA. Memandang kasus ini, Kemendag memiliki kepentingan secara ekonomi dan politik.

Kepentingan ekonomi Kemendag adalah menjamin penghapusan hambatan perdagangan yang diterima oleh Indonesia terhadap akses pasar produk Indonesia di negara anggota WTO, dalam hal ini adalah Amerika Serikat. Ini menjadi penting karena produk hukum FSPTCA ini merupakan tindakan yang melanggar salah satu prinsip WTO, yaitu prinsip non-diskriminasi.

Setidaknya ada dua tindakan diskriminasi yang terlihat, yaitu 'totally banned" dan "like products". Pada dasarnya, negara hanya boleh mengatur aktivitas perdagangan, bukan untuk melarang aktivitas perdagangan (totally banned) dan itulah yang terjadi dalam konteks FSPTCA yang dilakukan oleh Amerika Serikat terhadap Indonesia (Sulistyo 2019). Meskipun produk hukum FSPTCA ini diciptakan untuk menjaga kepentingan, kesehatan nasional Amerika Serikat, tidak semestinya mereka melakukan "totally banned" karena dalam sistem perdagangan multilateral, suatu negara tidak diijinkan untuk itu. Selanjutnya, terlihat ketika FSPTCA ini melarang semua bentuk produksi, pelabelan, pemasaran rokok beraroma/berasa (flavoured cigarettes) semisal vanilla, strawberry termasuk di dalamnya rokok kretek (produk khas Indonesia), tetapi tidak dimasukkan rokok menthol (produk domestik Amerika). Inilah poin utamanya: rokok kretek dilarang oleh FSPTCA tetapi tidak untuk rokok menthol yang padahal keduanya adalah "like products", karena memiliki aroma. Dengan kata lain, tindakan ini dirasa melanggar prinsip national treatment (diskriminasi terhadap suatu produk, yakni rokok kretek).

Di sisi lain, Kemendag berkepentingan secara politik bahwa setiap negara anggota WTO wajib mematuhi prinsip-prinsip perdagangan secara berkeadilan yang telah diatur dalam sistem WTO. Direktur Jenderal Kerjasama Perdagangan Internasional, Imam Pambagyo, menyatakan bahwa cukup mengherankan bahwa Amerika Serikat yang selalu menuntut negara lain agar patuh pada perjanjian-perjanjian WTO kini tidak melakukan tindakan koreksi atas kebijakannya yang jelas-jelas melanggar ketentuan WTO. Sulit dipahami bahwa Pemerintah Amerika Serikat yang sering mempermasalahkan kebijakan negara lain sebagai tidak sesuai dengan disiplin WTO kini justru mengabaikan kewajibannya yang juga diatur di WTO ("Indonesia Kecewa atas Ketidakpatuhan AS dalam Kasus Larangan Rokok Kretek").

Inilah yang menjadi dasar penting Indonesia untuk mengsengketakan produk hukum FSPTCA ke dalam DSB WTO. Belum lagi dampak nyata dari tindakan diskrimnasi ini, yaitu Indonesia mengalami kerugian secara ekonomi yang ditaksir oleh Indonesia sebesar 200 juta USD termasuk 
potensi hilangnya keuntungan dari aktivitas perdagangan (future lost). Di lain sisi, paska disahkannya produk hukum FSPTCA tahun 2009, aktivitas perdagangan Indonesia dengan Amerika Serikat khususnya rokok kretek menjadi terhenti $(0 \%)$, padahal sebelumnya terjadi peningkatan signifikan aktivitas perdagangan rokok kretek.

Belum lagi dampak politiknya bahwa Amerika Serikat sebagai negara adidaya dikawatirkan menjadi role model bagi negara-negara lain untuk melakukan tindakan serupa. Bila Amerika Serikat pun bisa melakukan pelanggaran prinsip WTO yang telah disepakati, maka negaranegara lain pun bisa melakukan hal tersebut. Inilah yang menjadi salah satu kekhawatiran bagi Indonesia dan dunia internasional, timbul negaranegara yang ingin melakukan tindakan serupa. Maka, wajar jika Indonesia mengejar kepentingan ekonomi dan politiknya melihat dampak yang ditimbulkan.

Selama proses Dispute Settlement Mechanism (DSM), Kemendag berpandangan bahwa Amerika Serikat harus mematuhi hasil rekomendasi panel dan badan banding yang menetapkan FSPTCA sebagai tindakan diskriminasi dan menyesuaikan hasil rekomendasi ke dalam FSPTCA. Pada perjalanan kasusnya, Amerika Serikat tak kunjung melakukan hal tersebut yang membuat Indonesia geram dan mendapatkan otoritas untuk melakukan retaliasi terhadap Amerika Serikat. Menariknya adalah retaliasi tak kunjung terlaksana, melainkan Amerika Serikat menawarkan Indonesia untuk mengakhiri kasus ini melalui mutually agreed solution, tidak melalui jalur retaliasi dari WTO.

Kemendag berpandangan untuk segera menerapkan tindakan retaliasi yang telah diatur sesuai dengan ketentuan dari WTO, yang mana retaliasi pada umumnya adalah dengan menaikkan tarif masuk produk dari Amerika Serikat, bukan menandatangani MoU (Sulistyo 2019). Pada intinya, Kemendag tetap mengedepankan penerapan retaliasi sesuai dengan sistem perdagangan multilateral (WTO) yang telah diatur secara resmi. Namun, karena nuansa politisnya tinggi, kedua pihak sepakat untuk mengambil retaliasi melalui mutually agreed solution.

Merujuk pada beberapa penjelasan sebelumnya, bila dianalisis berdasarkan preferensi dari Kemendag, besaran biaya dari no-agreement bagi Kemendag adalah tinggi. Hal ini dikarenakan Kemendag sebagai institusi pemerintah bertanggung jawab segala aktivitas perdagangan, termasuk untuk segera menyelesaikan sengketa perdagangan FSPTCA, terlebih ini menyangkut kepentingan nasional Indonesia. Selanjutnya, walaupun biaya dari no-agreement-nya tinggi, Kemendag termasuk ke dalam isolationist karena menginginkan sikap yang diambil oleh Indonesia 
adalah menerapkan tindakan retaliasi sesuai nilai yang telah diotorisasi oleh DSB WTO. Meskipun ini merupakan tindakan disahkan oleh WTO, dengan mengambil tindakan retaliasi sesuai dengan nilai otorisasi DSB WTO ini agaknya serupa dengan tidak menginginkan kompromi atau kerjasama. Lebih lanjut, preferensi dari Kemendag lebih bersifat homogen (boundary conflict) karena terjadi dilemma kepentingan antara Kemendag yang mengingatkan bahwa tindakan retaliasi itu dengan mengenakan bea masuk (tariff) terhadap barang impor negara lawan sesuai dengan nilai yang telah diotorisasi dan kementerian atau lembaga lain yang ingin menerapkan retaliasi dengan mutually agreed solution dengan beberapa pertimbangan politis. Terakhir, tingkat partisipasi dari Kemendag sangat tinggi karena berperan sebagai focal point pada level internasional dan pemrakarsa pada level domestik.

\section{Kementerian Luar Negeri (Kemenlu)}

Posisi yang diambil oleh Kemenlu dalam proses penyelesaian sengketa perdagangan FSPTCA hanya terlibat dalam rapat koordinasi yang diselenggarakan oleh Kemendag. Dalam prosesnya, Kemenlu hanya memberikan masukan atau pertimbangan politis kepada Kemendag sebagai focal point sekaligus pemrakarsa dalam kasus ini. Hal tersebut dikarenakan kasus FSPTCA bukan menjadi tupoksi kerja dari Kemenlu. Meskipun sengketa perdagangan FSPTCA ini lebih mengarah kepada aspek perdagangan atau perekonomian, tidak bisa dielakkan pula bahwa ada aspek-aspek politis yang terkandung di dalamnya. Pada fase inilah Kemenlu memaksimalkan posisinya dengan memberikan pertimbangan kepada pihak-pihak terkait. Dapat dikatakan bahwa Kemenlu memiliki kepentingan politis dalam kasus ini.

Kepentingan politis yang diambil oleh Kemenlu adalah meningkatkan hubungan bilateral dan kerjasama dengan negara dan organisasi dari Amerika dan Eropa sekaligus menjadi salah satu tujuan dari kemenlu ("Strategic Purposes of the Indonesian Foreign Policy"). Maka, dalam kasus ini, ketika Amerika Serikat tak kunjung menyesuaikan hasil rekomendasi panel maupun badan banding ke dalam FSPTCA serta keinginan Indonesia untuk melakukan retaliasi sesuai dengan nilai yang telah diotorisasi oleh DSB WTO, posisi Kemenlu tidak menginginkan retaliasi itu terjadi. Dalam konteks ini, Putnam menjelaskan kepentingan politik ini bertujuan untuk menghindari defection yang berakibat fatal pada prospek kerjasama bilateral lainnya dengan Amerika Serikat dikarenakan biaya politik dan diplomatik yang tinggi. Apabila Indonesia melakukan retaliasi sesuai dengan nilai yang telah diotorisasi DSB WTO, maka dikhawatirkan 
Amerika Serikat akan melakukan retalisi balasan setara atau lebih besar, atau berakibat pula pada aspek-aspek bilateral lainnya.

Pergeseran retaliasi yang terjadi dengan melakukan mutually agreed solution bukan sesuai dengan nilai otorisasi DSB WTO tidak lepas dari pertimbangan dari Kemenlu. Kemenlu mengambil posisi melalui mutually agreed solution didasarkan bahwa Indonesia memiliki hubungan baik dengan Amerika Serikat. Hal tersebut dimaksudkan untuk menjadi pertimbangan ketika Indonesia ingin melakukan retaliasi (Widayanto 2019). Juga dikhawatirkan bahwa hubungan baik selama ini yang sudah ada antara Indonesia dengan Amerika Serikat akan tercederai akibat tindakan retaliasi ini.

Tidak hanya itu, Kemenlu mengirimkan surat kepada Kemendag agar tidak melakukan retaliasi sesuai nilai yang diotorisasi DSB WTO karena Indonesia masih butuh kerjasama perdagangan, industri, dan investasi dengan Amerika Serikat (Widayanto 2019). Dengan kata lain, Kemenlu ingin menyampaikan bahwa jangan sampai tindakan retaliasi ini mengganggu kerjasama perdagangan, industri, investasi, pendidikan dan lain sebagainya antara Indonesia-Amerika Serikat yang memiliki trend positif.

Dianalisis menurut preferensi dari Kemenlu, besaran biaya dari noagreement (status quo) bagi Kemenlu adalah tinggi. Hal ini disebabkan oleh risiko tinggi karena Indonesia melakukan defection yang berakibat buruk bagi hubungan atau kerjasama yang terjalin antara Indonesia Amerika Serikat yang sudah berjalan baik.

Selanjutnya, Kemenlu dapat dikategorikan internationalist karena menginginkan Indonesia menyelesaikan secara kooperatif atau kompromi, yaitu melakukan retaliasi dengan mutually agreed solution. Dalam konteks ini, mutually agreed solution erat kaitannya dengan tindakan positif (kompromi), meskipun hal tersebut dikatakan sebagai tindakan retaliasi dalam konteks lain. Lebih lanjut, preferensi Kemenlu bersifat homogen (boundary conflict) karena terjadi dilemma kepentingan antara Kemenlu yang mengingatkan bahwa tindakan retaliasi dapat mengganggu hubungan baik yang sudah ada dan Indonesia masih bergantung dengan Amerika Serikat, namun bertentangan dengan Kemendag yang menginginkan tindakan retaliasi sesuai dengan nilai yang telah diotorisasi oleh DSB WTO. Terakhir, tingkat partisipasi dari Kemenlu cukup tinggi karena selalu aktif dalam berbagai rapat koordinasi dengan Kemendag bahkan bisa mempengaruhi hasil dengan menjaga hubungan baik. Dari analisis tersebut, dapat disimpulkan bahwa preferensi Kemenlu mempengaruhi ukuran win-set Level II sehingga ukuran win-set nya besar. 
Kamar Dagang dan Industri Indonesia (KADIN)

Umumnya kehadiran KADIN di dalam proses penyelesaian sengketa perdagangan FSPTCA ini sudah mewakili Aliansi Masyarakat Tembakau Indonesia (AMTI) dan Gabungan Perserikatan Pabrik Rokok Indonesia (GAPPRI). Namun, AMTI dan GAPPRI tetap diundang dalam beberapa rapat koordinasi untuk mengetahui kondisi secara langsung. Dalam kasus FSPTCA, masing-masing pihak memandang dari perspektif yang berbeda, namun dengan tujuan yang serupa, yaitu pemerintah Indonesia harus bersikap tegas terhadap Amerika Serikat sebagai balasan dari tindakan diskriminasi FSPTCA, salah satunya dengan mensengketakannya kedalam DSB WTO.

GAPPRI memiliki poin kepentingan untuk mewakili kepentingan para industri rokok. Dalam kasus ini, GAPPRI bersuara keras karena menganggap bahwa rokok kretek itu adalah ikon rokok khas Indonesia untuk memperkuat posisi Indonesia pada sengketa ini (Widayanto 2019). Hal ini sangat penting untuk menunjukkan bahwa pemerintah Indonesia bersungguh-sungguh dalam prosesnya karena menyangkut dengan barang khas yang bernilai budaya tinggi dari Indonesia. Kepentingan lainnya adalah bahwa GAPPRI turut memperhatikan efek domino lainnya yang menimpa kepada para buruh industri rokok kretek (Widayanto 2019). Maka bisa dikatakan bahwa ada efek domino yang panjang ketika undangundang FSPTCA ini berlaku. Masalah pada ekspor rokok kretek ke Amerika Serikat berdampak pula pada industri rokok kretek yang akhirnya berdampak pula pada para buruh yang bekerja di indutri tersebut.

Di lain sisi, AMTI merupakan representasi dari para petani atau masyarakat yang bersinggungan langsung dengan tembakau. AMTI menilai bahwa kasus FSPTCA berdampak pada perekonomian para petani tembakau yang menggantungkan hidupnya pada komoditi tembakau (Widayanto 2019). Menjadi wajar ketika AMTI turut aktif dalam sengketa perdagangan FSPTCA karena berdampak pada perekonomian masyarakat kecil yang bergantung pada tembakau atau rokok kretek semisal petani tembakau. Hambatan-hambatan FSPTCA dirasakan betul oleh para petani tembakau Indonesia sebagai mata pencahariannya. AMTI juga menerangkan ada dua juta petani tembakau, 12.5 juta petani cengkeh dan 600 ribu pekerja (buruh) pabrik rokok kretek sehingga dapat dibayangkan akibat undang-undang FSPTCA ini terhadap banyak petani dan pekerja.

Selain itu, KADIN mengambil peranan untuk memberikan pertimbangan kepada kementerian atau lembaga lainnya dengan berfokus pada aspek perdagangan. KADIN memandang aktivitas perdaganganlah 
yang menentukan keberlangsungan dari sebuah industri (Widayanto 2019). Aktivitas perdagangan yang terganggu berdampak bagi keberlangsungan industri termasuk rokok kretek. KADIN mengatakan satu pabrik rokok kretek Indonesia sudah satu tahun membuka usaha di Amerika Serikat melihat pangsa pasar yang luas, tapi terhambat perluasan investasinya bahkan harus tutup akibat disahkannya undang-undang FSPTCA ("Kadin Sesalkan Larangan Rokok Kretek di Amerika"). Pertimbanganpertimbangan inilah yang membentuk win-set Indonesia untuk dibawa ke level internasional (Level I). Kehadiran KADIN di dalamnya dipandang sebagai asosiasi yang menaungi AMTI dan GAPPRI dan paham betul aspek aktivitas perdagangan internasional. Di beberapa kesempatan, GAPPRI dan AMTI hadir untuk menjelaskan kondisi nyata yang ada.

Menariknya, paska rekomendasi Badan Banding atas kasus FSPTCA keluar, KADIN diundang rapat koordinasi untuk menentukan langkah selanjutnya, di mana hasilnya sepakat bahwa Indonesia meminta otorisasi terhadap WTO untuk melakukan retaliasi begitupun pada kesepakatan mutually agreed solution. Pada fase ini, AMTI dan GAPPRI tidak lagi diikutsertakan dalam pengambilan keputusan karena tindakan retaliasi itu sifatnya government to government dan mempercayakan kepentingan mereka kepada KADIN karena ketidakpahaman menyeluruh secara substansi. Kehadiran KADIN sendiri pun hanya diberikan informasi bahwa seperti inilah keputusan yang disepakati oleh pemerintah Indonesia karena mereka hanya sebagai interested parties dan sudah tidak menjadi yang utama lagi (Widayanto 2019). Jika sudah pada tahap keputusan untuk melakukan retaliasi, maka sepenuhnya berada di tangan pemerintah. Alasan lainnya adalah hasil dari retaliasi tidak bisa dikompensasikan terhadap pihak yang dirugikan (AMTI \& GAPPRI) dan mereka tidak bisa mengklaim hasil retaliasi tersebut. Terlebih nilai retaliasi tersebut bisa dimanfaatkan oleh pemerintah Indonesia untuk sektor berbeda yang benarbenar dibutuhkan Indonesia.

Berdasarkan pada penjelasan-penjelasan di atas, besaran biaya preferensi no-agreement (status quo) mereka adalah rendah. Hal itu didasarkan pada tahapan Indonesia ingin melakukan tindakan retaliasi baik secara nilai yang telah diotorisasi DSB WTO maupun dengan mutually agreed solution. AMTI dan GAPPRI tidak lagi menjadi penting karena tindakan retaliasi sudah berada antar pemerintah (bersifat $G$ to G). Terlebih, hanya KADIN yang diikutsertakan dan sekedar menerima informasi kebijakan yang diambil oleh pemerintah Indonesia. Selanjutnya, sikap mereka digolongkan ke dalam isolationist karena mengharapkan 
pemerintah Indonesia bertindak cepat dan tegas terhadap Amerika Serikat akibat kerugian yang ditimbulkan dari tindakan diskriminasi undangundang FSPTCA. Terakhir, tingkat partisipasi dari mereka terbilang rendah karena mereka hanya menerima informasi atas kebijakan yang diambil oleh pemerintah Indonesia.

Dari penjelasan preferensi dan koalisi Level II dari aktor-aktor domestik di atas dapat dianalisis lebih mendalam bahwa ukuran win-set Level II untuk tidak melakukan tindakan retaliasi sesuai dengan nilai otorisasi DSB WTO terhadap Amerika Serikat dalam kasus FSPTCA didominasi oleh Kemendag dan Kemenlu. Penjelasannya adalah bahwa kasus sengketa perdagangan internasional merupakan tupoksi kerja Kemendag, sekaligus menjadi focal point dan pemrakarsa dalam beberapa perundingan maupun rapat koordinasi antar kementerian dan lembaga. Sementara di sisi lain, Kemenlu memiliki poin kepentingan memberikan masukan atau pertimbangan. Tapi, mereka mengingatkan jangan sampai keputusan tindakan retaliasi membuat hubungan Indonesia - Amerika Serikat menjadi tidak harmonis dan Indonesia masih bergantung baik dari segi investasi dan industri, dan menginginkan keputusan yang kooperatif atau kompromi. Pada akhirnya, pemerintah Indonesia tidak melakukan tindakan retaliasi sesuai dengan nilai yang diotorisasi oleh DSB WTO, melainkan melakukan tindakan retaliasi yang terlihat seakan kooperatif, yakni mutually agreed solution.

Dari sisi ukuran retalif, kekuatan isolationist (pihak yang tidak cenderung kooperatif) dan internationalist (pihak yang cenderung kooperatif/memberikan dukungan) relatif seimbang. Kemendag termasuk ke dalam kelompok isolationist mendukung bahwa pemerintah harus bertindak tegas dan cepat, salah satunya melalui tindakan retaliasi sesuai nilai yang telah diotorisasi. Sementara Kemenlu tergolong kelompok internationalist karena mendukung penyelesaian sengketa perdagangan FSPTCA ini dengan cara kooperatif yang diidentikkan melalui tindakan retaliasi dengan mutually agreed solution.

Sedangkan dari preferensi tingkat partisipasi, Kemenlu dan Kemendag menunjukkan tingkat partisipasi yang tinggi sehingga berpeluang menciptakan peluang yang sejajar. Pada dasarnya, semua aktor tersebut sepakat bahwa jika ingin melakukan retaliasi atau tidak melakukan retaliasi sesuai nilai yang diotorisasi oleh DSB WTO semua pertimbangan dari semuanya menjadi penting dan terakomodir sehingga memperbesar ukuran win-set. Hal inilah yang membuat ukuran win-set Level II menjadi tumpang tindih seperti pada Gambar 1. 


\section{Gambar 1}

Ukuran Win-Set Level II Berdasarkan Preferensi dan Koalisi Level II

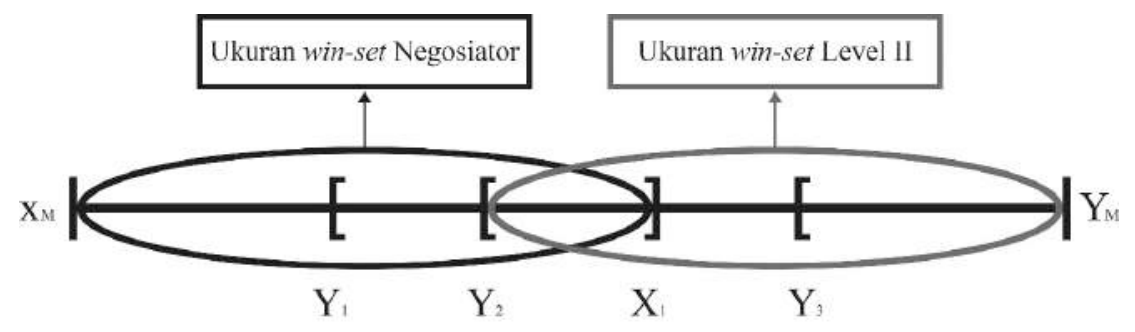

Sumber: Diolah dari Putnam (1988)

\section{Institusi pada Level II}

Menurut Putnam, institusi Level II (domestik) ini terdiri dari dua unsur penting, yaitu prosedur ratifikasi dan besaran otonomi pemerintah dari tekanan domestiknya. Tahap ini lebih menekankan pada bagaimana prosedur ratifikasi yang dilakukan pemerintah untuk melahirkan sebuah kebijakan, apakah harus dengan mengeluarkan undang-undang atau cukup dengan peraturan menteri dan sebagainya. Besaran otonomi pemerintah dari tekanan domestik menekankan pada seberapa besar pemerintah mengambil kebijakan secara independen, tanpa ada lagi campur tangan pihak luar.

Penyelesaian sengketa perdagangan FSPTCA yang diakhiri dengan retaliasi mutually agreed solution berpedoman pada Undang-Undang Nomor 7 Tahun 2014 tentang Perdagangan (Widayanto 2019). Undangundang tersebut menyebutkan bahwa perlindungan dan pengamanan perdagangan dilakukan oleh Menteri (perdagangan). Dengan kata lain, prosedur ratifikasi penyelesaian sengketa perdagangan semua berada kuasa penuh menteri perdagangan, tidak harus mendapatkan persetujuan dari lembaga pemerintah lainnya semisal Presiden atau DPR, sehingga penyelesaian kasus FSPTCA menjadi lebih mudah serta Kemendag merasa untuk mengakhiri kasus FSPTCA ini cukup dengan mutually agreed solution.

Penggunaan UU No. 7 tahun 2014 ini sudah tepat. Pertama, kasus FSPTCA ini lebih condong ke dalam aspek perdagangan dan karena 
itu kasus ini sudah menjadi tugas tupoksi dari Kemendag atau dapat diselesaikan pada tingkat kementerian (perdagangan), meskipun ada aspek politis di dalamnya. Kedua, FSPTCA merupakan sebuah produk hukum Amerika Serikat yang awalnya bertujuan untuk melindungi kesehatan warganya dari penyakit yang ditimbulkan akibat rokok. Namun, seiring berjalannya waktu timbul tindakan diskriminasi dengan melarang secara keseluruhan rokok kretek termasuk Indonesia, tetapi tidak untuk rokok menthol asal domestik Amerika Serikat. Sehingga banyak kerugian yang diakibatkan dari penerapan undang-undang FSPTCA ini. Produk hukum FSPTCA ini menjadi bagian dari salah satu poin yang dimaksud dalam kebijakan perlindungan dan pengamanan perdagangan, yaitu pembelaan terhadap ekspor barang nasional yang dirugikan akibat penerapan kebijakan dan atau regulasi negara lain. Yang bertanggung jawab pada kebijakan perlindungan dan pengamanan perdagangan adalah menteri perdagangan.

Poin berikutnya adalah besaran otonomi pemerintah dari tekanan domestik. Besaran otonomi pemerintah dalam kasus ini adalah besar atau tekanan domestik menjadi kecil. Hal itu didasarkan pada bahwa pada tahapan retaliasi sudah berada di bawah kendali antar pemerintah ( $G$ to $G$ ). Disamping itu, hasil kompensasi kerugian yang diakibatkan dari FSPTCA tidak selalu dialokasikan kepada pihak yang dirugikan (industri rokok kretek, AMTI, GAPPRI), bisa dialokasikan ke sektor lainnya (Widayanto 2019). Menurut Putnam (1988), negara dengan besaran otonomi besar tidak terlalu sulit untuk menuju sebuah kesepakatan karena tidak ada lagi pemangku kepentingan (swasta) sebagai bargaining advantage saat berhadapan dengan pihak lawan di Level I (internasional). Karena itu, pemerintah Indonesia bebas menentukan sikap untuk tidak menerapkan retaliasi sesuai nilai yang diotorisasi DSB WTO terhadap Amerika Serikat, melainkan melakukan retaliasi dengan mutually agreed solution.

Dengan demikian, proses ratifikasi penyelesaian sengketa perdagangan FSPTCA berada di bawah kuasa menteri perdagangan, tidak melibatkan lembaga lainnya, dan tidak perlu menggunakan Perpres maupun Undang-Undang, melainkan hanya sebatas MoU. Oleh karena itu, hal ini menjadi lebih mudah dan lebih cepat untuk mencapai sebuah kesepakatan. Besarnya otonomi pemerintah dalam mengambil sebuah keputusan turut andil dalam mempengaruhinya karena pada tahapan retaliasi sudah berada di bawah kendali antar pemerintah, tidak ada lagi desakan dari pemangku kepentingan (pihak swasta) yang aktif sehingga pemerintah lebih mudah mencapai kesepakatan di Level I (internasional) dan tidak ada lagi bargaining advantage bagi Indonesia. 
Berdasarkan penjelasan institusi Level II di atas, ukuran win-set Level II berada di $\mathrm{Y}_{2}$ menjadikannya tumpang tindih dengan ukuran winset negosiator yang berada di $\mathrm{X}_{1}$. Oleh karena itu, ukuran win-set Level II dapat diilustrasikan sebagaimana pada Gambar 2.

\section{Gambar 2}

Ukuran Win-set Level II Berdasarkan Institusi Level II

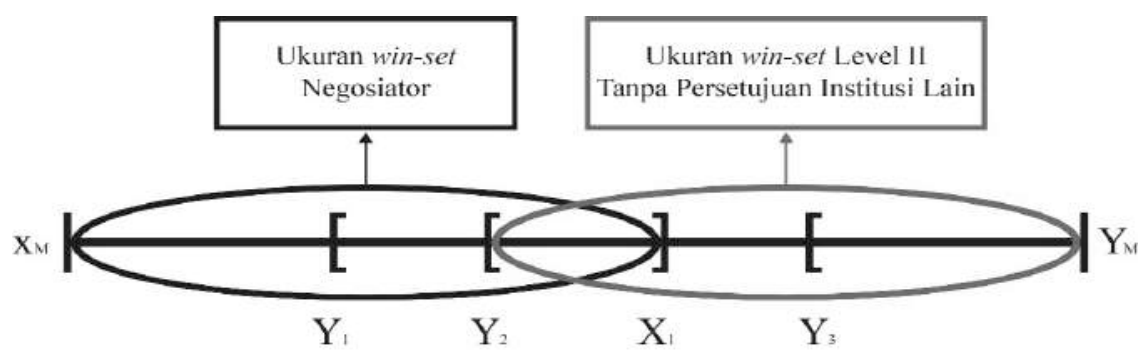

Sumber: Diolah dari Putnam (1998)

\section{Strategi Negosiator}

Dalam strategi negosiator, terdapat dua unsur penting, yaitu side payment dan generic good will (Putnam 1998). Side payment merupakan satu cara memperbesar ukuran win-set dengan mencari dukungan dari pendukung marjinal serta besarannya dihitung sesuai kontribusi marjinal yang memungkinkan untuk ratifikasi. Dengan kata lain, pemerintah akan memberikan perlakuan atau penawaran bagus bagi pendukung marjinal yang tentunya dengan harapan mereka akan memperbesar win-set dan berujung pada peluang besar untuk ratifikasi. Sementara itu, generic good will adalah all-purpose glue untuk koalisinya untuk memperbesar winset walaupun tidak menjamin proses ratifikasi pada Level I. Pendukung marjinal akan menyerahkan semua keputusan dengan beberapa alasan mungkin karena ketidakpahaman akan substansi atau negosiatornya merupakan pemimpin politik tertinggi sehingga mengikuti apa saja yang diputuskan dengan membuat opini publik.

Yang menarik adalah kasus FSPTCA penggunaan strategi side payment tidak menjadi strategi andalan bagi negosiator. Jika pada penjelasan sebelumnya penggunaan strategi ini untuk menarik pendukung marjinal untuk memperbesar win-set dan mempermudah ratifikasi, maka dalam kasus ini tidak ada pendukung marjinal. Hal ini disebabkan bahwa pada tahapan retaliasi sudah berada di bawah kendali penuh pemerintah, 
termasuk sikap tidak dilakukannya tindakan retaliasi sesuai dengan nilai otorisasi DSB WTO, melainkan tindakan retaliasi dengan mutually agreed solution.

Tidak ada lagi AMTI, GAPPRI dan KADIN sebagai pemangku kepentingan (pihak swasta), meskipun pada sebelumnya sangat bersuara. Ketika sudah masuk tahapan retaliasi, mereka tidak diperhitungkan kembali (Widayanto 2019). Hasil dari kompensasi atas kerugian yang mereka rasakan tidak bisa lagi diklaim ke dalam rokok kretek, hanya nilainya saja, dan itu pun tidak mesti semuanya masuk kedalam produk rokok kretek karena pemerintah bisa mengalokasikannya ke produk lain. KADIN hanya diinformasikan atas keputusan yang diambil oleh pemerintah.

Dari segi generic good will, KADIN dan non-state actor lainnya paham bahwa pada tahapan retaliasi ini menjadi domain pemerintah sehingga mempercayakan keputusan terbaik kepada pemerintah. Tentunya hal tersebut tidak terlepas generic good will dari pejabat tinggi Kemendag. Jika bagi Putnam (1988) yang memberikan generic good will adalah yang memiliki kedudukan politik tertinggi di negaranya (pemimpin negara) karena memiliki kuasa paling tinggi, maka dalam kasus FSPTCA generic good will hanya sebatas pada pejabat tinggi Kemendag. Hal ini bisa saja disebabkan karena ketidaktahuan presiden atau orang-orang di sekitarnya atau itu secara politis tidak bernilai lagi. Di sisi lain, penyelesaian kasus ini menjadi domain menteri perdagangan sesuai dengan pedoman UU No. 7 Tahun 2014 tentang perdagangan.

Dengan demikian, pemerintah Indonesia berhasil memperbesar ukuran win-set Level II (domestik) dengan strategi yang dijalankan menjadi tumpang tindih dengan ukuran win-set negosiator sebagaimana dalam Gambar 3. Pada akhirnya, ratifikasi pada Level I (internasional) menjadi lebih memungkinkan dan tujuan politik pemerintah Indonesia untuk mengakhirinya dengan retaliasi dengan mutually agreed solution yang lebih kooperatif tercapai.

\section{Gambar 3}

Ukuran Win-set Level II Berdasarkan Strategi Negosiator

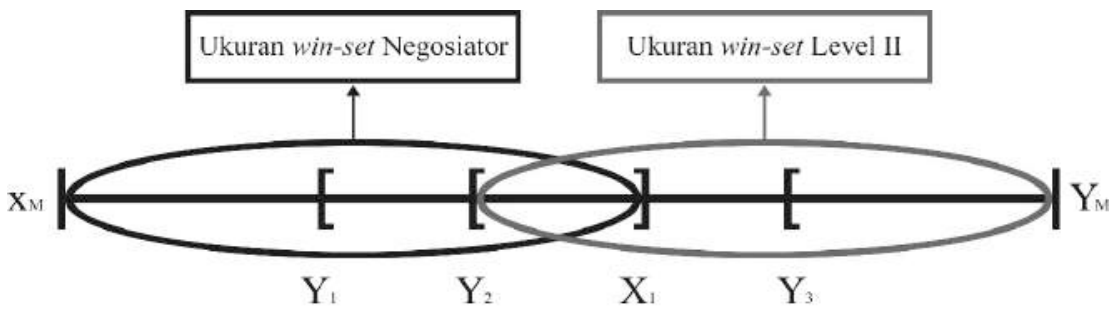

Sumber: Diolah dari Putnam (1988) 
Dalam proses pembentukan win-set pada Level I (internasional, yang menarik adalah adanya pergeseran posisi Indonesia dari retaliasi menaikkan bea masuk (tarif) terhadap satu barang dari pihak lawan sesuai dengan nilai otorisasi DSB WTO ke pilihan retaliasi dengan mutually agreed solution. Padahal Indonesia telah mendapat otorisasi dari WTO untuk melakukan retaliasi terhadap Amerika Serikat.

Poin-poin dalam mutually agreed solution dirasa oleh Indonesia lebih signifikan ketimbang nilai otorisasi retaliasi DSB WTO, yaitu USD 55 juta. Tidak diterapkannya retaliasi ini lebih dikarenakan membesarnya ukuran win-set pada Level I (internasional karena adanya tawaran dari Amerika Serikat untuk mengakhiri sengketa perdagangan FSPTCA dengan mutually agreed solution. Karena itu, pertimbangan keuntungan lebih besar yang didapatkan oleh Indonesia membuat ukuran win-set menjadi tumpang tindih. Ukuran win-set yang tumpang tindih menjadikan kedua belah pihak tidak sulit untuk mencapai kesepakatan sebagaimana dalam Gambar 4.

\section{Gambar 4}

Ukuran Win-set Tidak Diterapkannya Retaliasi Sesuai Nilai Otorisasi DSB WTO Melainkan Mutually Agreed Solution

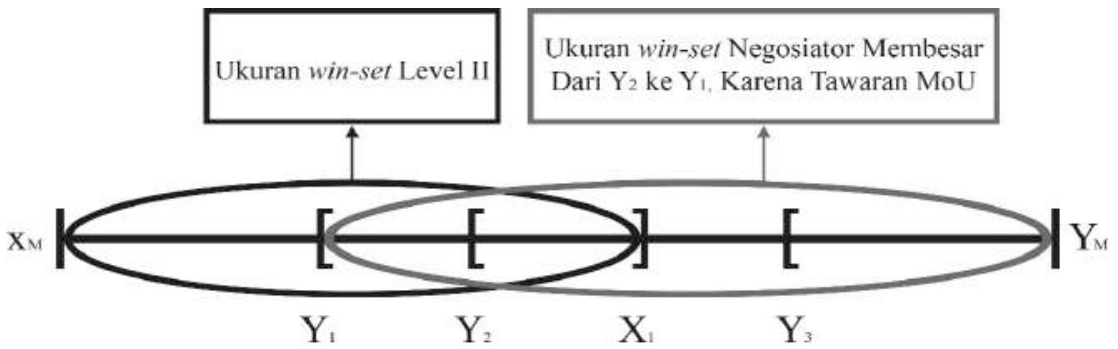

Sumber: Diolah dari Putnam (1988)

Dalam Gambar 4 terlihat win-set Level II berada pada $\mathrm{X}_{1}$ dan win-set Level I (negosiator) berada pada $Y_{1}$ sehingga tumpang tindihnya menjadi besar kemungkinannya. Ukuran win-set yang berada pada $\mathrm{X}_{1}$ dan $\mathrm{Y}_{1}$, melambangkan hasil maksimal yang bisa diratifikasi oleh kedua belah pihak. Dengan kata lain, pemerintah Indonesia baru akan meratifikasi penyelesaian sengketa perdagangan ini berada pada $X_{1}$ didasarkan pada kesepakatan pada Level II untuk secara tegas dan cepat merespon tindakan diskriminasi Amerika Serikat, yaitu dengan menerapkan retaliasi. Namun, 
dengan adanya tawaran MoU dari Amerika Serikat terhadap Indonesia untuk menyelesaikan sengketa perdagangan dianggap memperbesar ukuran win-set Level I, yang minimal berada pada $\mathrm{Y}_{2}$ menjadi melebar berada pada $Y_{1}$ sehingga ratifikasi penyelesaian sengketa perdagangan FSPTCA melalui retaliasi dengan mutually agreed solution memiliki peluang besar.

\section{Kesimpulan}

Adanya pergeseran retaliasi yang dilakukan oleh Indonesia dari yang seharusnya menaikkan bea masuk (tarif) sesuai dengan nilai otorisasi DSB WTO ke retaliasi dengan mutually agreed solution menjadi poin menarik sebagai akhir dari kasus sengketa perdagangan FSPTCA. Secara preferensi dan koalisi, tidak diterapkannya retaliasi dengan nilai yang telah diotorisasi DSB WTO kepada Indonesia terhadap Amerika Serikat merupakan hasil interaksi antar aktor domestik (Kementerian Luar Negeri, Kementerian Perdagangan, dan beberapa kelompok tembakau domestik) yang mempengaruhi ukuran win-set pada Level II (domestik) sekaligus mempengaruhi ukuran win-set Level I (internasional).

Secara institusi di level II (domestik), penyelesaian sengketa perdagangan ini sebatas pada tingkatan menteri sesuai dengan UU No. 7 Tahun 2014 tentang perdagangan sehingga penyelesaian pun pada tingkat menteri sudah cukup, tidak mesti melibatkan lembaga lainnya seperti DPR, dan tahapan retaliasi tersebut berada pada kuasa penuh pemerintah. Karena itu, besaran otonomi dalam kasus ini sangat besar atau tekanan domestiknya kecil. Pada sisi strategi negosiator yang terjadi pada Level I (internasional), penggunaan strategi side payment tidak lagi digunakan karena tidak ada kelompok marjinal untuk mendukung ratifikasi tidak diterapkannya retaliasi sesuai nilai otorisasi DSB WTO. Strategi generic good will digunakan karena pemangku kepentingan (pihak swasta) tidak lagi paham substansi dari retaliasi dan mengikuti apapun hasil yang diputuskan oleh pemerintah, yang dalam kasus ini diwakili oleh pejabat Kemendag.

Pada Level I (internasional) terjadi pembesaran ukuran win-set yang dibawa oleh Amerika Serikat dengan menawarkan untuk menyelesaikan sengketa perdagangan FSPTCA melalui mutually agreed solution, yang dirasa lebih signifikan oleh pemerintah Indonesia. Hal itu membuat ukuran win-set Level II (domestik) tumpang tindih dengan ukuran win-set Level I (internasional) sehingga kesepakatan ratifikasi penyelesaian sengketa perdagangan FSPTCA lebih besar kemungkinannya. 


\section{Referensi}

Arisanto, Puguh Toko. 2017. "Trade Controversy Amidst Tobacco Control Provisions: Dynamics on the Establishment of U.S Tobacco Control Act 2009." Jurnal Ilmiah Hubungan Internasional 13(2): 171-85. DOI: 10.26593/jihi.v13i2.2626.171-185.

Ballet, Lucas. 2011. "Losing Flavor: Indonesia's WTO Complaint Against the U.S. Ban on Clove Cigarettes." American University International Law Review 26(2):515-41.

Bjola, Corneliu, and Ilan Manor. 2018. "Revisiting Putnam's Two-Level Game Theory in the Digital Age: Domestic Digital Diplomacy and the Iran Nuclear Deal." Cambridge Review of International Affairs 31(1):3-32. DOI: 10.1080/09557571.2018.1476836.

“Current Status of Disputes.” Diakses pada 6 Mei 2018 dari (https:// www.wto.org/english/tratop_e/dispu_e/dispu_current_status_e. htm).

da Conceição-Heldt, Eugénia, and Patrick A. Mello. 2017. Two-Level Games in Foreign Policy Analysis. New York: Oxford University Press.

Davey, William J. 2005. "The WTO Dispute Settlement System: How Have Developing Countries Fared?". Illinois Public Law Research Paper No. 05-17.

Dermawan, Windy, and Annisa Rohmaniah. 2019. "Peran Indonesia dalam Kerjasama Asean-Korea Selatan Melalui Asean-Korea Centre." JISPO Jurnal Ilmu Sosial Dan Ilmu Politik 9(1):470-89.

"Family Smoking Prevention and Tobacco Control Act - An Overview."

Diakses pada 13 Pebruari 2019 dari (https://www.fda.gov/ TobaccoProducts/GuidanceComplianceRegulatoryInformation/ ucm246129.htm).

Fie, Alfaini Husna, Rowena Marsha Devy, and Yusniar Dwi Agustin. 2015. "Legalisasi Memorandum of Understanding (MOU) Sebagai Sarana dalam Mengakhiri Sengketa Perdagangan Internasional (Studi Kasus Sengketa Rokok Kretek Indonesia-Amerika Serikat)." Privat Law 7:50-56.

"Kadin Sesalkan Larangan Rokok Kretek di Amerika." Diakses dari (https://www.beritasatu.com/ekonomi/10483/kadin-sesalkanlarangan-rokok-kretek-di-amerika-).

Keisuke, Ilda. 1993. "When and How Do Domestic Constraints Matter? Two-Level Games with Uncertainty." Journal of Conflict Resolution 37(3):403-26. 
"Indonesia Kecewa atas Ketidakpatuhan AS dalam Kasus Larangan Rokok Kretek". Kementrian Perdagangan RI, Jakarta.

"Indonesia dan AS Sepakat Akhiri Sengketa Rokok Kretek." Diakses pada 23 September 2018 dari (www.beritasatu.com/ makro/215653-indonesia-dan-as-sepakat-akhiri-sengketa-rokokkretek.html).

Mo, Jongryn. 1995. "Domestic Institutions and International Bargaining: The Role of Agent Veto in Two-Level Games." American Political Science Review 89(4):914-24. DOI: 10.2307/2082517.

Nasution, S. 2001. Metode Research (Penelitian). Jakarta: Bumi Aksara.

Neuman, W. Lawrence. 2014. Social Research Methods: Qualitative and Quantitative Approaches. 7th ed. London: Pearson Education Limited.

Oktavian, Alif. 2012. "Analisis tentang Menangnya Kasus Rokok Kretek Indonesia oleh WTO.” Jurnal Westphalia 11:122-34.

Purnama, Chandra, Windy Dermawan, and Emil Mahyudin. 2019. "Democratic Transition and Reflection on Indonesia'S Efforts To Encourage Democratization in Myanmar." JISPO Jurnal Ilmu Sosial Dan Ilmu Politik 9(2):310-38.

Putnam, Robert D. 1988. "Diplomacy and Domestic Politics: The Logic of Two-Level." International Organization 42(3):427-60. DOI: 10.1017/cbo9781139683487.003.

"RI Sengketakan Larangan Perdagangan Rokok Kretek di Amerika Serikat ke DSB-WTO”. Kementrian Perdagangan RI, Jakarta.

"Strategic Purposes of the Indonesian Foreign Policy." Diakses 12 Mei 2019 dari (https://kemlu.go.id/portal/en/read/19/halaman_list lainnya/strategic-purposes-of-the-indonesian-foreign-policy).

"United States-Measures Affecting the Production and Sale of Clove Cigarettes (Request for Consultations by Indonesia)." Diakses pada 6 May 2018 dari (https://docs.wto.org/dol2fe/Pages/FE_ Search/FE_S_S009-DP.aspx).

Voon, Tania. 2012. "United States-Measures Affecting the Production and Sale of Clove Cigarettes." The American Journal of International Law 106(4):824-30. DOI: 10.5305/ amerjintelaw.106.4.0824.

Winarno, Budi. 2014. Dinamika Isu-Isu Global Kontemporer. Yogyakarta: CAPS. 
“WTO Kembali Menangkan Kasus Rokok Kretek Indonesia.” Diakses dari (https://money.kompas.com/read/2012/04/06/17203199/ WTO.Kembali.Menangkan.Kasus.Rokok.Kretek. Indonesia?page $=$ all)

"WTO Perkuat Putusan Kemenangan RI Soal Kretek." Diakses pada 18 September 2018 dari (https://tekno.kompas.com/ $\mathrm{read} / 2012 / 04 / 05 / 09590957 /$ wto.perkuat.putusan.ke)

Wawancara

Dengan Sulistyo Widayanto, January 2019. 